\title{
Public Relations and New Media in Employee Relations for Enhancing Employee's Loyalty During the Pandemic
}

\author{
Trifosa Joan Ervani ${ }^{1 *}$, Lina Sinatra Wijaya ${ }^{2}$
}

1,2 Universitas Kristen Satya Wacana, Salatiga, Jawa Tengah, Indonesia

\section{ARTICLE INFO}

\section{Article history:}

Received June 14, 2021

Revised June 20, 2021

Accepted July 28, 2021

Available online August 25, 2021

Keywords:

Public Relations, New Media, Employee Relations, Employee Loyalty

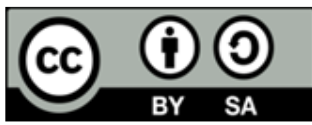

This is an open access article under the CC BY-SA license.

Copyright $(2021$ by Author. Published by Universitas Pendidikan Ganesha.

\begin{abstract}
A B S T R A C T
The Covid 19 pandemic occurred nowadays has resulted in many employees resigning due to discomfort at work. Therefore, every company needs to carry out an employee relations program to increase employee's loyalty, especially during this pandemic. The aim of this study is to determine the employee's loyalty which was formed by the implementation of the employee relations program carried out by Public Relations using new media during the pandemic. Data collection is done by conducting observations, documentation, and interviews. The results of this study shows that there are five forms of employee relations programs done to increase employee's loyalty, among others, education and training programs, outstanding work motivation programs, award programs, special event programs, and internal communication media programs. The success of those employee relations program are shown by a decrease in the percentage of employee resignation, from $40 \%$ to $20 \%$ in one year. Evidence of employee's loyalty formed by the employee relations program can also be seen from several attitudes and actions of employees that include obedience and compliance, responsibility, willingness to cooperate, sense of belonging, interpersonal relationships, and fondness for work. In addition, personal touch to employees has the greatest impact to increase employee's loyalty to the Company.
\end{abstract}

\section{INTRODUCTION}

The pandemic caused by coronavirus disease (COVID-19) has spread globally in more than 121 countries in the world. According to expert from health faculty in Indonesia University (FKM UI), coronavirus disease appeared in Indonesia around the $3^{\text {rd }}$ week of January and spread into 34 provinces in Indonesia with the most cases in Jakarta (detikNews, 2020). Not only has an impact on health, the pandemic also has an impact on the economy, especially for companies in Indonesia. Based on a survey conducted by the Ministry of Manpower (Kemnaker), the Indonesian Institute of Sciences (LIPI), and the Demographic Institute of FEB UI, 96.5\% of companies in Indonesia affected by this pandemic (Katadata.co.id, 2020). This resulted in a decrease in revenue and the closure of various company operations. One of the main problems caused by the large number of employees who resign from the company is due to low employee loyalty for various reasons. As stated by Susiwijono Moegiarso, the secretary of the Coordinating Ministry for Economic Affairs, as many as 1.3 million employees resigned from the company while the layoffs were only around 285,000 employees (Tirto.id, 2020).

To achieve the Company's goals, it is necessary to have employees who give their best and are aware of their roles in the Company (Rachman dan Dewanto, 2016). Employees are very important potential that can be developed within a company (Teguh, et.all, 2018). It is said that the success of a company will not be separated from the loyalty, totality, and productivity of employees at work. We need to know that employee's loyalty, totality, and productivity also depend on harmonious and conducive communication within the company, because this will increase the motivation and the morale of the employees. Unfortunately, many companies focus too much on revenue levels and marketing strategies rather than internal company communications, especially with their employees. It is not surprising that many employees feel uncomfortable and unappreciated so they start moving to other companies with higher job offers or higher salaries, especially when Indonesia is still experiencing a pandemic situation (Noerchoidah, 2020).

This situation will certainly be very detrimental to the company if many employees resign because the company will be forced to re-prepare the budget for recruitment and training for new employees, and 
other needs. The loss will be felt, especially if those who decide to move from companies are senior employees or employees who have worked for a very long time in the company (Faaroek, 2020). This research was conducted in one of the companies in Indonesia located in West Jakarta. In this study, the Company's identity will not be mentioned in this article, due to the request of the Company. All matters relating to the name of the company will be referred to as company X or PT.X.

In a company, communication practitioners such as Public Relations (PR) are needed to resolve communication barriers that exist within the company through various programs such as employee relations. Employee relations is intended to build mutual understanding and reciprocity between fellow employees and employees with management (Putriani, 2017). Research from Kartika dan Aninditio (2017) said that employee relations programs are important to do and have significant effect on employee motivation. However, since the pandemic in Indonesia, people are required to do everything digitally to minimize the infection of the corona virus. Research from Norhabiba dan Putri, (2018) said that new media can make people more open, able to find information, and add new friends. In addition, new media can also increase the solidity of relationships and facilitate community activities or society activities.

Not only the general public, the Company's employees are also required to do their work from home. This activity is already known as Work From Home (WFH) which is a new working system during the pandemic, where people can do the work without coming to the office and have a fairly high flexibility of working hours (Mungkasa, 2020). Therefore, many companies have taken advantage of new media based on internet technology such as the Cisco Webex Meet platform to carry out various types of activities including employee relations programs (Junep, 2016). Like how Public Relations is, Company X has implemented various employee relations programs using Cisco Webex Meet so that employees can remain solid and feel family even though they do not meet face to face in the office. This is proved by the very good relations between employees and they help each other even though Work From Home (WFH) using various platforms to facilitate communication so that they almost never experience facing problems in the company, especially problems between individuals.

As one of the largest IT subsidiaries in Indonesia, Company X engaged in IT solution services for customers who encounter IT problems. With international quality standards certified to ISO 9001:2000, quality management system certified with ISO 9001:2015, as well as information security management system certified with ISO/IEC 27001:2013, Company X has already had various types of IT services to satisfy customers as described in Company X's website. Company X is also a company that really cares about the welfare and comfort of its employees by implementing employee relations program using new media during the pandemic in order to increase employees' sense of belonging to the company. Most employee relations programs also come from employee suggestions submitted to the company. This means that Company X not only considers employees as objects of the employee relations program, but they are also subjects of the program so that employees feel being involved in decision-making, feel valued, and cared by the Management or the Company.

It is common for the Director of Company $\mathrm{X}$ to immediately conduct video conferences with employees to ask what they want and need in their work while they are still in WFH condition. He also tries to get to know his personality and familiarize himself with all employees who work at Company X. This is an interesting phenomenon and very rare in one of the largest IT companies in Indonesia. This uniqueness has attracted attention and interest for further research on the employee relations program run by Company $\mathrm{X}$ that using new media and succeeded in increasing employee loyalty to company during the pandemic.

The purpose of this research is to find out how Public Relations uses new media in implementing employee relations programs at Company $\mathrm{X}$ and to find out whether the employee relations programs that have been implemented can increase employee loyalty in Company X. The focus of this qualitative research is the employee relations program that are being carried out to increase employee loyalty during the pandemic.

\section{METHODS}

This research was conducted using a qualitative method with a case study research design. Qualitative research is research that provides data that is in accordance with the actual situation. This research use snowball sampling which is based on interviews or correspondence, which will ask for information from the first sample to get the next sample until the research sample needs are met (Putra, 2017). The sample in this study consisted of two key persons and nine resource persons who were used to provide information about the employee relations program implemented, the situation, and the condition of the research background. The sampling population is limited to the Application Development Division (ADD), because this division is one of the divisions with the largest number of employees and is one of the 
most important divisions that has a major role in Company $\mathrm{X}$ considering that this company is engaged in IT solution services. This research use observation, interviews, and documentation as data collection techniques to get answers and data as complete as possible. Due to the pandemic, data collection was carried out online using video conference. Online observation is a research method by observing a mechanism that occurs online (Bryman, 2021). Online interview is a research method by conducting computer-mediated communication, such as short message service, e-mail, or video conference $\left(\mathrm{O}^{\prime} \mathrm{Connor}\right.$ dan Madge, 2017).

\section{RESULTS AND DISCUSSIONS}

\section{Results}

\section{Employee Relations Program in Application Development Division (ADD) Using New Media}

The employee relations program has been carried out by Company X even before the pandemic occurred in Indonesia. Management calls this program not by the name of employee relations but engagement program, so in this article, the name of employee relations and the engagement program will be used interchangeably. The purpose of the engagement program carried out by the management is to build good relations and create a bond between the Company and its employees. In addition, the engagement program is also intended as a media to relieve fatigue for employees who experience fatigue both physically and emotionally, so that employees can feel comfortable and complete in doing their work again. This was conveyed by the key person Ms. Silvia Kristiani as the relationship manager and Mrs. Marlina as the division manager:

\section{Ms. Silvia Kristiani: \\ "Sebenarnya engagement program dari kata enaggement-nya adalah dari kata kerja ikat, jadi bagaimana kita membuat sebuah keterikatan antara Perusahaan dengan karyawan ..." \\ ("Actually, the engagement program comes from the word engagement, which is from the verb- engage, so how do we make an engagement between the Company and employees ...") \\ Mrs. Marlina: \\ “... tujuan kita meng-engage orang itu untuk merekatkan hubungan satu sama lain agar orang merasa nyaman dan memberikan yang terbaik dari usahanya ..." \\ ("... our goal of engaging a person is to bond with each other so that people feel comfortable and give the best out of their efforts...")}

With the engagement program, the Company can find out the conditions and situations that are being faced by employees so that the Company can try to help employees who are having difficulties. Company X not only provides services to consult with management, but also provides money loan services for employees who are having economic difficulties with several terms and conditions. In addition, the good relationship between management and employees allows employees to express their thoughts and ideas for new innovations that can be given to the Company more easily. Although good relationship that exists between employees and management are good and quite close, employees still uphold respect and they also respect for each other due to the bond formed through the engagement program. Through the engagement program, employees will feel valued and cared to create a good working climate that can stimulate employee's loyalty and productivity (Rahmi, et.all, 2018). Due to this good working climate, employees will have high motivation to work and perform their job duties as much as possible (Jaya, 2020).

Even though we are in a pandemic period that requires employees to work from home and not have physical meetings with other employees, the Company still wants that employees loyalty to the Company will continue to increase by participating in the employee relations program. To maximize this goal, apart from the several engagement programs that have been implemented, the management also performs personal touch to communicate with employees more closely. Personal touch is intended so that the management is able to recognize and understand the character of each employee more optimally. This program is carried out by management to its employees once a week and is usually carried out on the first day of the week. In the personal touch program conducted by management, employees are welcome to share their complaints while working. But in practice, employees often share their personal problems and ask for solutions from management. With this condition, management can leverage its employees more optimally because they can get to know their employees more closely and get rid of the limitations of employees fears of management without losing respect for each other (Nifadkar, et.all, 2018). Key persons Ms. Silvia Kristiani and Mrs. Marlina also shared their opinions about the importance of personal touch during the pandemic: 


\begin{abstract}
Ms. Silvia Kristiani:
“... Engagement program yang efektif adalah personality engagement. Karena setiap karyawan yang sudah di-engage secara personal itu mau tidak mau pasti loyal."

("... An effective engagement program is personality engagement. Because every employee who has been personally engaged will inevitably be loyal.")

Mrs. Marlina:

“... Tapi kalau terhadap team inti yang banyak berinteraksi dengan aku, engagement itu aku lakukan secara personal. Jadi aku selalu set up setiap minggu ada satu jadwal untuk satu orang ..."

("... But when it comes to the core team that interact with me a lot, I will do the engagement personally. So I always set up one schedule for one person every week ...")
\end{abstract}

Personal touch performed by management can make employees feel not alone and can rely on management in terms of providing solutions for the employees. Management uses personal touch more often to employees because interpersonal relationships create understanding in the psychological process, or personal touch can affect employees psychologically. This makes employees feel more cared for and be able to tell the problems directly to management (Putriani, 2017).

During the pandemic, management used several new media platforms to conduct engagement programs, including the Cisco Webex Meetings and Microsoft Teams video conferencing platforms. The reason for using the new media platform to carry out engagement programs is based on efforts to limit the possibility of corona virus transmission if you meet in person, and support the Large-Scale Social Restrictions (PSBB) policy issued by the Government (Adawiyah dan Kadir, 2020). The choice of using the two platforms mentioned earlier is due to a collaboration between Company $\mathrm{X}$ and the two companies owned the platform products. Therefore, the management already has a license for the product which allows management to access the premium features provided by each platform as said by the key person, Ms. Silvia Kristiani:

“... Terutama saat ini dari team HR sudah ada yang memiliki license Webex, jadi kita biasa pakai Webex. Yang kedua kita juga biasa pakai Microsoft Teams meskipun untuk menampung peserta itu lebih sedikit daripada Webex, karena kita juga punya license-nya ..."

("... Especially now that the HR team has already had a Webex license, so we usually use Webex. Secondly, because we also have the license, we also usually use Microsoft Teams, although it is less than Webex to accommodate participants....")

The use of new media is done so that employees can comply with Government policies by not having to come to the office but still being able to participate in the engagement program held by management. In addition, employees and management can still feel face to face interaction with each other virtually so that it seems as if they are meeting face to face. Not only that, new media also allows employees and management to share photos, videos, and other documents to make it easier for communicators to explain material by packaging many messages in one visual product (Khairil, 2018). Management also utilizes new media to request feedback from employees through forms or polls during the engagement program, so that management can find out the type of engagement program needed by the employees.

The choice of platform is always adjusted to the number of participants in the engagement program. If the participants in the engagement program is more than the limit that can be accommodated by the Microsoft Teams platform, then management will use the Cisco Webex Meetings platform. On the other hand, employees are getting used to it and knowing the platforms that are often used for certain engagement programs. Besides minimizing the disease transmission, using new media makes it easier for employees to participate in the engagement programs because new media is internet-based and can be accessed from anywhere and anytime (Junaerdi dan Sukmono, 2020).

There are several engagement program activities carried out by Public Relations of Company X, namely education and training programs or commonly referred to as training in the Application Development Division (ADD) and organized by Human Resource (HR) Training which is now renamed to learning development. The training is divided into two, namely technical and soft skills which are held every month. The training held is usually in the form of workshops so that employees can practice optimally. In addition, there is also training that has a higher level to obtain certification by completing an exam with a predetermined value after participating in the training provided. It is not uncommon for employees to be financed by Company $\mathrm{X}$ to participate in prestigious certifications from other companies. 
The Application Development Division (ADD) also conducts an educational program called the IT training program. This program is intended for fresh graduate students and is carried out for two months at Company X. After two months, participants in the IT training program have immediately become contract employees at Company X. The program language used in this IT training program is divided into two, namely Java and DotNet. To be able to find out the skills of the participants, the trainer will conduct interviews with prospective participants to make selection and division of training classes. Management has a guideline that the higher the employee's skills, the more satisfying the results of the employee's work. This can be seen from the management who does not hesitate to pay for employee certification even though the price is quite expensive. Therefore, employees can make a greater contribution to the Company with education and training programs, because employees can develop knowledge and skills continuously that can be applied to work (Widijanto, 2017).

Achievement work motivation program in which the Company provides informal awards as an award for employees who are able to exceed the Key Person Index (KPI) target set by each manager in each Division. The form of awards given before the pandemic and during the pandemic was quite different. Before the pandemic, the awards were given in the form of gold or gold bars, while during the pandemic the awards were given in the form of monetary incentives. An example of giving an award is if an employee can win the employee of the month program. The employee of the month award will be announced by management every month to appreciate employee performance and motivate other employees to maximize their performance in carrying out the working assignments (Wasis, 2018).

Employees who get awards will try to do their best at work, because employees feel that the Company is aware of the importance of the existence of employees, so that employees feel cared for, cared for, and developed by the Company (Raturoma dan Wijaya, 2018). In addition, the informal award program can make employees feel accepted and recognized by the Company, because the Company rewards employees hard work that can exceed the targets set by management (Suparmi dan Septiawan, 2019).

The award program is given to employees who have more performance than other employees or provide new innovations for the Company. This award is given at the beginning of every quarter or every three months for employees who have excellent performance, such as being able to work on projects in a short time or with a lot of work time remaining. The highest award is given at the beginning of each year for employees who have the best performance and have the greatest positive impact among other employees such as creating projects or innovations that can be used for the development or progress of the Company. Prior to the pandemic period, the award was given in the form of a vacation or trip abroad which was divided into Asia and Europe depending on the level of achievement obtained by the employee. Employees with a high enough level of innovation achievement will be awarded a trip to Asia, while employees with the highest level of innovation achievement will be awarded a trip to Europe. However, during this pandemic, the award is converted into incentive money which is divided into two nominal or with different amounts according to the level of achievement of the employee.

In the implementation of this award program, there are various other competitions such as photo or video competitions, and also tiktok for employees who want to share their ideas and abilities. In each competition category, two to three winners will be drawn for getting shopping vouchers or e-money prizes which nominal value is adjusted to the winners. In addition, there are also entertainment programs such as music performances from other employees to enliven the event and also provoke employees to take their minds off their work for a moment. Usually, this award ceremony is held before the big meeting of the Application Development Division (ADD) and the big annual event of Company X.

The award program is carried out as a form of remuneration or gifts to employees for certain jobs that are of high value to the Company. This program can also be a motivation or encouragement for employees who have not received awards to be more active and total in their work, because employees will have a high desire to compete for awards by improving their abilities and performance (Prabu dan Wijayanti, 2016).

The special event program is realized in the form of a Webinar so that employees can share their knowledge or experiences even during the pandemic. Webinars are seminars that are conducted online and are intended for employees to keep on communicating and getting information or materials even though they are doing their working from home (WFH) (Durahman dan Noer, 2019). Topics or materials given in the Webinar will be selected based on the results of feedback from employees or can be said to be in accordance with the ideas and desires of employees. Examples of webinars that have been held during the pandemic are about cycling, cooking, yoga or sports, make-up for women, vacations or vacation spots in Indonesia, how to play stocks, and others. At each Webinar, the committee will give a quiz with prizes to find out how focused the employees are in participating in the Webinar held. The quiz is given using the Quiz platform which has various features that make quiz participants feel as if they are playing a video game. In addition, a feedback form is also provided at the end of the event so that employees can submit criticisms 
or suggestions on the engagement program carried out. In the pre-pandemic period, many special events were held in the form of sports such as football, badminton, and others. In addition, there are also other events such as prayer fellowships, ngabuburit, division outings, karaoke, and others.

Through special event programs, employees can temporarily relieve their workload by enjoying the events that are held because the special event programs held are always tailored to the needs of their employees through ideas or input from employees so that it can be said that management is trying to meet the needs of employees out of the technical skills or soft skills. With a special event program, employees can do refreshing together which is of course to establish and maintain good relationships and eliminate the workload that has been done so far (Hasibuan, 2018). For Internal communication media program, the company uses email communication media to convey information, so the management can always encourage and direct the employees to frequently view or open their emails. Even though employees on the site have emails with the office domain where the employees are located, employees will still receive email notifications or notifications from the Application Development Division (ADD) of Company X so that employees will keep on receiving the up to date information provided by management.

Besides using email, management also continues to provide information through the Whatsapp group through the team leader in each project group. Due to this condition, if employees forget to open their emails, employees can still get information from announcements broadcast in each project group. Not only through team leaders, but relationship managers from each project will also remind their employees to take part in the engagement program that will be implemented by management. The internal communication media program is intended to keep in touch with employees through intermediary media. With this program, employees can always get the latest information about engagement programs or other announcements more easily. In addition, this internal communication media program is carried out to maintain good relations between management and employees which create two-way communication opportunities by asking for feedback, questions, and attention from employees (Herpridjihan dan Utami, 2020). The participation and enthusiasm of the employees in participating in the engagement program carried out by the management is quite good, it can be seen from the responses and initiatives of employees when participating in the engagement program where many of the employees asked the resource persons for tips, suggestions, experiences, and others. The key person, Mrs. Marlina, said:

“... Pernah juga kita sampai kehabisan durasi karena banyak sekali yang bertanya ke speaker-nya, entah yang minta tips, minta saran, tanya harga, atau tanya pengalaman ..."

("... Once, We've also run out of time because so many people asked to the speaker about the tips, advice, prices, or experiences ...")

Sometimes, due to the duration of the engagement program has expired, employees are directed to be able to ask to the resource persons via email or social media that was given at the beginning of the event. Employees are also involved in planning and implementing engagement programs with the aim of increasing employees sense of belonging towards the Application Development Division (ADD) and Company $\mathrm{X}$, as well as being a form of marketing or an invitation to other employees to participate in the engagement program. The intended form of marketing here is the marketing promotion that is called a word of mouth marketing strategy where employees become promoters of the engagement program implemented by management. With this strategy, employees who act as promoters can attract greater attention and interest from other employees to participate in the engagement program because of their high trust so that other employees will consider more in joining the program (Rohandi, 2016). This was conveyed by the key person, Ms. Silvia Kristiani:

"Kalau keterlibatan karyawan itu pasti, jadi kalau kita buat suatu program, buat suatu event, itu
untuk karyawan dan dari karyawan juga ... Kalau karyawan itu terlibat, biasanya mereka beritahu
temannya ... Jadi itu salah satu bentuk marketing juga menurut aku ... karyawan punya sense of
belonging dimana event ini juga milik mereka, mereka juga terlibat di engagement program ini ..."
("The employee involvement is certain, so if we make a program, create an event, it's for employees
and from employees too ... If employees are involved, they usually tell their friends ... So that's also a
form of marketing in my opinion. .. employees have a sense of belonging because this event is also
theirs, they are also involved in the engagement program ...")

The purpose of employees being included in the planning and implementation of the engagement program is to increase the sense of belonging of employees to support the Company in achieving its goals, because the Company also pays attention to the contributions made by employees by giving awards and attention the employees through the engagement programs (Baliartati, 2016). In addition, the role of 
employees in planning and implementing engagement programs makes the program more appropriate in achieving or meeting employee targets or needs.

The implementation of the engagement program carried out by management is inseparable from the obstacles that can occur at any time. Even so, management does not consider obstacles as problems but as challenges that must be resolved. Some examples of obstacles that occur along with the resolutions carried out by management are when the engagement programs takes a long time, then management will prepare for a long time even from several days to months in advance. Another obstacle that often occurs is the engagement program schedule that usually collided with the work of employees so that employees will be asked to complete the task first if the engagement program implemented is not too urgent or contains important information. If the engagement program implemented is quite important at the Company or Division level, then employees are required to participate in the engagement program first. For management, the completion of the engagement program constraints during this pandemic is obtained by facing the obstacles first so that they can find out the steps or decisions that must be taken to resolve these obstacles, as stated by the key person, Mrs. Marlina:

“... Jadi kita belajar by doing it, tidak seperti biasanya kita belajar karena diajarkan, tapi waktu pandemi kita belajar dengan melakukan."

("... So we learn by doing it, not as usual, we tend to learn because we are taught, but during the pandemic we learn by doing.")

It can be said that management continues to learn from experience so that it can improve the quality of the engagement program implemented by not repeating the same mistakes as the previous one (Kurniawan, 2017). Employees also continue to support the implementation of the engagement program by continuing to provide feedback and enthusiastically following the engagement program conducted by the management.

\section{Employee Relations Program to Maintain Employees' Loyalty}

Company $\mathrm{X}$ always strives to meet the welfare and needs of employees in carrying out their work, both in terms of soft skills and hard skills through the engagement program implemented. In addition, the Company also hopes that with the engagement program, employees can have high morale so that they can create behavioral attitudes that are in accordance with the Company's culture. Employees who have participated in engagement program activities have proven to be more total in their work because they can apply what they get from the engagement program. Another reason Company X thinks that welfare and needs of employees is important, is to motivate and make employees comfortable, because employees are one of the most important assets in the Company's business continuity (Pitoy, et.all, 2020).

The engagement program held by Company $\mathrm{X}$ is comprehensive and can be followed by all its employees. But this turned out to be less effective in increasing employee's loyalty, especially in the Application Development Division (ADD) which at that time was still under the Manage Service Business Unit (MSBU). In 2019, the Application Development Division (ADD) has just been developed and established separately with the Manage Service Business Unit (MSBU) which was the previous shelter. This decision was taken because the Manage Service Business Unit (MSBU) was unable to manage the Application Development Division (ADD) at that time, so many employees quit or resigned. Due to this condition, the management decided to separate the Application Development Division (ADD) and the Manage Service Business Unit (MSBU) so that the Application Development Division (ADD) management could focus on improving and developing its employees in various aspects.

Management fights for its employees to get their rights as proper employees in the Company, not just as robots who work and are not cared for. The steps taken by management in an effort to develop their employees prove that management really cares and does not just take advantage of employees, because remembering that the function of management is to be responsible for managing human resources and other resources to achieve the desired goals (Rahmi, et.all, 2018). In addition, management sees great potential in the employees of the Application Development Division (ADD) so that they entrust the Application Development Division (ADD) to be able to stand alone and explore existing skills and jobs.

The decisions taken by management and the engagement program carried out to equip and also improve relations between employees, produced satisfactory results and proved quite successfu. It can be seen from the employee's turnover data in the Application Development Division (ADD) obtained from Human Resources (HR) from Company X: 
Tabel 1. Employee Turnover Data (\%) in Application Development Division (ADD)

\begin{tabular}{cc}
\hline Tahun & Turnover Karyawan (\%) \\
\hline 2019 & $40 \%$ \\
2020 & $20 \%$ \\
\hline
\end{tabular}

During the separation of the Application Development Division (ADD) from the Manage Service Business Unit (MSBU), the percentage of employee turnover in the Application Development Division (ADD) was $40 \%$. This is because many employees who have run out of contract periods, are not managed properly by the Manage Service Business Unit (MSBU) in 2019. Therefore, in 2020 management is trying to pay more attention and convince employees that the Application Development Division (ADD) really cares about their employees by using engagement programs that are held every week or month. After a long process, data on the percentage of employee's turnover has decreased quite significantly to $20 \%$. From the results of interviews with the two key persons, it can be seen that employees feel more cared for by the Company with the engagement program implemented because employees can convey their ideas or aspirations to management more easily through the feedback form (Rahayu, et.all, 2019). There are several elements of loyalty that can be seen from Application Development Division (ADD) employees, namely obedience and compliance, responsibility, willingness to cooperate, sense of belonging, interpersonal relationships, and love for work. Based on the results of interviews, most of the Application Development Division (ADD) employees comply with the regulations and duties assigned by the Company. This can be seen from several events, for example, employees are required to participate in engagement programs such as large meetings or other major events. Employees will leave their job temporarily and immediately follow the ongoing engagement program.

\section{Discussion}

In addition, employees also obey the work standards set by management and override the standards owned by the employees themselves. In general, employees also comply with office working hours starting at 08.00 WIB and ending at 17.00 WIB even though they are working from home (WFH). This is due to the good relationship or closeness between management and employees which causes the tendency of employees to obey the rules that have been set and not against to the management policies (Larastrini dan Adnyani, 2019). Application Development Division (ADD) employees generally have good responsibilities and it can be seen from their work that is always on time and also in accordance with the wishes of management. Not even a few employees are willing to spend time outside of the working hours to complete their work assignments. For example, not a few employees try to complete their work assignments until the early hours of the morning and also give up a few hours on their days off at the weekends to do the working assignments.

The form of employee responsibility for their work is to meet management expectations by always quickly and responsively revising their duties so that they can be used immediately even though on the other hand employees continue to follow the engagement program. In other words, employees give their best effort in carrying out work tasks to achieve predetermined targets. The sense of responsibility of employees grows along with the sense of comfort obtained from management work services, due to a sense of satisfaction as an aspect of employees who are able to improve their employees' performance and are closely related to employees' productivity at work (Katili dan Kaluku, 2017). Almost all employees of the Application Development Division (ADD) are assigned to tasks that require them to cooperate with other employees. This is due to the large number of projects in the Application Development Division (ADD) that cannot be done by just one person. Although there are individual tasks, most employees choose to keep asking questions or collaborating with other employees through private chat. Not only that, employees usually try to be able to cooperate with other employees who have never collaborated with them before, such as asking for help from employees in different fields.

The collaboration carried out by employees has a positive impact which can be seen from the many achievements of the employee team obtained by the Application Development Division (ADD). There are even employees who get awards up to five times a year and are being proposed for two more awards in the near future due to good teamwork in creating and developing projects that can be used by all Company employees. The best results are obtained from good cooperation and will not be separated from good relations between employees, because teamwork will always depend on interaction and coordination in completing tasks to achieve common goals (Lawasi dan Triatmanto, 2017).

Most of the employees of the Application Development Division (ADD) show that they have a sense of belonging to the Company. This sense of belonging is shown by employees giving their best effort or totality in doing work assignments. An example is when an employee is given an assignment, the employee does not do it carelessly but does a survey first or sees an example of a task that has existed before. In 
addition, the employee's sense of belonging is contained in their participation in activities carried out by management, for example participating as an event organizer or committee. Another thing is because employees already think that the Company is their second family, employees will try to help other employees who need help even though they are not clearly asked for help. Although based on the results of interviews, it is shown that almost all employees have a sense of belonging to the Company, it is true that employees have a sense of belonging to the Company after working for a sufficient or relatively long time. In other words, employees who have worked in Company X longer have a greater sense of belonging than employees who have just joined the Company, because the sense of belonging is a sense that is closely related to inner attachment and is not just a sense of belonging to the Company due to the business (Afryana, 2018).

Employees in the Application Development Division (ADD) of Company $\mathrm{X}$ are required to have close friends or what is commonly referred to as an inner circle. So that in general, Application Development Division (ADD) employees have good relationships with other employees. Even though they are not people in their inner circle, employees are still friendly because it is based on the Company's culture and also the legacy or example of what the management has applied to its employees. However, it is different from the employees who have recently joined the Company, because they are still trying to adapt and also do not have good friends or inner circle. Good relations between employees cannot be separated from the occurrence of conflicts that can occur at any time with the most common reason that is miss communication. However, when a conflict occurs, the Application Development Division (ADD) employees are accustomed to solving problems by talking or discussing with the parties concerned. If a good solution cannot be found, mediation will be carried out by the project head or management. Good interpersonal relationships will create a conducive and harmonious working environment, because as the relationship building process progresses, the awareness and willingness to fuse personal desires or self-selfishness for the common good will be created (Hasibuan, 2018).

When employees are asked to give a satisfaction rating from one to ten for the work that has been completed, based on the results of interviews, most employees give a score above seven. This is because employees feel they have given their best effort. If something goes wrong or doesn't work as intended, it's a human error and employees will try their best to fix it. Even so, there are some employees who still do not have confidence or are insecure about the results of their work. This employee still looks down on himself and is not very satisfied with the results of his work when it is compared to other employees' works. Most employees consider the given task is not a difficulty or obstacle but a challenge for employees to be able to develop and complete the task. If you look back, this is a principle passed down by management to its employees, that is "difficulty or hard task is not an obstacle, but a challenge that must be passed in order to develop". This is where employees think that when employees are getting used to the work given, then there is no difficult work or too much work. So if there is a job that is considered difficult, it means the employee has not given his best effort. Even though employees have quite a lot of workloads, employees still have a sense of liking for their work because employees can use their skills and abilities to do tasks with freedom and feedback provided by management (Monika, 2018).

\section{CONCLUSION}

Based on the results of the analysis and discussion, it can be concluded that the engagement program (employee relations) carried out by the Company's Application Development Division (ADD) management can increase employee loyalty to Company X. The percentage of employee turnover has decreased quite a lot, and significantly increase the productivity, motivation, and the totality of the employees increased compared to the condition before the engagement program was implemented. Management uses new media, especially Microsoft Teams and Cisco Webex Meetings as the platforms for conducting engagement programs during the pandemic. The use of new media is intended so that employees do not need to meet face to face, thus it can also minimize the infection of the corona virus. By using new media, employees and management can also participate in the engagement programs more flexibly or from anywhere and anytime. The three biggest factors that affect employee loyalty are having good relations between employees and management, giving awards, and developing the employee's competency through engagement programs, especially training. Another factor that supports the increase in employee's loyalty is a sense of belonging to Company $\mathrm{X}$ and also a special program tailored to the needs of the employees. The engagement program carried out by management received a good response from employees, because employees felt valued. Even so, management believes that the engagement program has more impact before the pandemic because they can see the expressions and conditions of employees directly. To overcome this, management performs personal touch in order to be able to keep on knowing and understanding the conditions and needs of employees during the pandemic. For further research, it 
would be better if the engagement program / employee relation is applied to a wider scope and not only in one division, and the research can be carried out using a quantitative approach to test how much influence the employee relations program has on employee's loyalty to the Company.

\section{REFERENCES}

Adawiyah, D. P. R., \& Kadir, N. (2020). Analisis Peran Media Dalam Upaya Pencegahan Penyebaran Virus Corona (Covid-19) di Indonesia. Jurnal Mediakita, 4 (1). https://doi.org/10.30762/mediakita.v4i1.2444.

Afryana, S. D. (2018). Pengaruh Employee Engagement Terhadap Sense of Belonging (Studi di Bandung Techno Park). Jurnal Indonesia Membangun, 17 (2), 45-57. (https://jurnal.inaba.ac.id/index.php/JIM/issue/view/12).

Baliartati, B. O. (2016). Pengaruh Organizational Support Terhadap Job Satisfaction Tenaga Edukatip Tetap Fakultas Ekonomi dan Bisnis Universitas Trisakti. Jurnal Manajemen dan Pemasaran Jasa, 9 (1), 3554. http://dx.doi.org/10.25105/jmpj.v9i1.1401.

Bryman, A. (2021). Bryman's Social Research Methods. Oxford: Oxford University Press.

Citra, L. M., \& Fahmi, M. (2019). Pengaruh Kepemimpinan, Kepuasan Kerja Dan Motivasi Kerja Terhadap Loyalitas Karyawan. Maneggio: Jurnal Ilmiah Magister Manajemen, 2 (2), 214-225. http://dx.doi.org/10.30596\%2Fmaneggio.v2i2.3776.

detikNews. (2020). Kapan Sebenarnya Corona Pertama Kali Masuk RI? Retrieved from https://news.detik.com/berita/d-4991485/kapan-sebenarnya-corona-pertama-kali-masuk-ri.

Durahman, N., \& Noer, Z. M. (2019). Aplikasi Seminar Online (Webinar) Untuk Pembinaan Wirausaha Baru. Jurnal Manajemen Informatika, 6 (2), 111-120. Retrieved from http://jurnal.stmikdci.ac.id/index.php/jumika/article/view/427.

Faaroek, A. (2020). Pengaruh Job Demand Terhadap Turnover Intention Melalui Burnout Pada Karyawan Work From Home, 17 (3), 384-396. Retrieved from https://ejurnal.esaunggul.ac.id/index.php/Formil/article/view/3680.

Hardiyanto, S. (2017). Pengaruh Employee Relation Terhadap Kepuasan Komunikasi Karyawan PDAM Tirtanadi Cabang Sei Agul. INTERAKSI: Jurnal Ilmu Komunikasi, 1 (1), 43-49. http://dx.doi.org/10.30596\%2Finteraksi.v1i1.878.

Hasibuan, H. M. S. P. (2018). Manajemen Sumber Daya Manusia - Edisi Revisi. Bumi Aksara.

Herpridjihan, S. B., \& Utami, L. S. S. (2020). Analisis Employee Relations melalui Training dalam Membangun Loyalitas Karyawan (Studi pada Karyawan Divisi Teknik PT. Pelita Air Service). Prologia, 4 (2), 303309. http://dx.doi.org/doi: 10.24912/pr.v4i2.6513

Jaya, A. (2020). Peran Komunikasi Opinion Leader Dalam Meningkatkan Elektabilitas Calon Kepala Daerah Di Sumatera Utara. Jurnal Massage Komunikasi, 9 (1) (https://jurnal.darmaagung.ac.id/index.php/messageilmukomunikasi/issue/view/71), 6-16.

Junaerdi, F., \& Sukmono, F. G. (2020). University Students Behaviour in Searching and Disseminating COVID19 Online Information. Jurnal Aspikom, 5 (2), 245-253. Retrieved from http://jurnalaspikom.org/index.php/aspikom/article/view/767/233.

Junep, A. R. (2016). Media Baru dan Komunikasi Organisasi (Studi Kasus Pemanfaatan Email, Yahoo!Mesengger, Lync, dan Portal Internal Dalam Komunikasi Internal PT Datacomm Diangraha). Jurnal Commed, 1 (1). (http://ejournal.upbatam.ac.id/index.php/commed/issue/view/20), 1329..

Kartika, R., \& Aninditio, A. (2017). Penerapan Program Employee Relations Dalam Meningkatkan Motivasi Kerja Karyawan di PT. PLN (PERSERO) Puslitbang. Communicology: Jurnal Ilmu Komunikasi, 5 (2), 1-26. https://doi.org/10.21009/communicology.062.01.

Katadata.co.id. (2020). Kemnaker Catat 96\% Perusahaan Terkena Dampak Pandemi Corona. Retrieved from https://katadata.co.id/agungjatmiko/berita/5efc879e27b5b/kemnaker-catat-96-perusahaanterkena-dampak-pandemi-corona.

Katili, A. Y., \& Kaluku, Y. (2017). Tanggung Jawab Karyawan Dalam Pelaksanaan Pekerjaan di Usaha Dagang Fahmi Meubel Kecamatan Kwandang Kabupaten Gorontalo Utara. Jurnal Manajemen Sumber Daya Manusia, 4 (2), 111-119. https://doi.org/10.37606/publik.v4i2.56.

Khairil, M. (2018). Analisis Pemanfaatan New Media Melalui Jaringan Media Sosial. National Conference of Creative Industry: Sustainable Tourism Industry for Economic Development, 772-779. Retrieved from https://journal.ubm.ac.id/index.php/ncci/article/view/1293/1106.

Kurniawan, B. (2017). Teori Kendala Sebagai Alat Pengukuran Kinerja. Jurnal Akutansi Bisnis, 9 (2), $211-$ 239. http://dx.doi.org/10.30813/jab.v9i2.882.

Larastrini, P. M., \& Adnyani, I. G. A. D. (2019). Pengaruh Kepuasan Kerja Lingkungan Kerja Dan Work - Life 
Balance Terhadap Loyalitas Karyawan. E-jurnal Manajemen, 8 (6), 3674-3700. https://ojs.unud.ac.id/index.php/Manajemen/issue/view/3054.

Lawasi, E. S., \& Triatmanto, B. (2017). Pengaruh Komunikasi, Motivasi dan Kerjasama Tim Terhadap Peningkatan Kinerja Karyawan. Jurnal Manajemen dan Kewirausahaan, 5 (1), 47-57. https://doi.org/10.26905/jmdk.v5i1.1313.

Monika, L. (2018). Implementasi Employee Relations Dalam Meningkatkan Motivasi Kerja Karyawan di PT PLN Area Pekanbaru. Jom Fisip, 5 Ed. 2, 1-14. Retrieved from https://jom.unri.ac.id/index.php/JOMFSIP/article/view/22407.

Mungkasa, O. (2020). Bekerja dari Rumah (Working From Home/WFH): Menuju Tatanan Baru Era Pandemi COVID 19. The Indonesian Journal of Development Planning, 4 (2), 126-150. https://doi.org/10.36574/jpp.v4i2.119.

Nasution, I. A. (2019). Peranan Public Relations Dalam Meningkatkan Pelayanan Informasi Hotel Garuda Plaza. Jurnal Warta, 13 (3), 138-149. https://doi.org/10.46576/wdw.v0i61.441.

Nifadkar, S. S., Wu, W., \& Gu, Q. (2018). Supervisors' Work-Related and Non-Work Information Sharing: Integrating Research On Information Sharing, Information Seeking, and Trust Using Self-Disclosure Theory. Personnel Psychology. Retrieved from https://www.researchgate.net/publication/326978383_The_power_of_personal_touch_Integrati ng_research_on_work_and_non work_information_sharing_information_seeking_and_trust_using_self-disclosure_theory.

Noerchoidah. (2020). Turnover Intention Karyawan: Pengaruh Budaya Organisasi, Organizational Justice dan Kepuasan Kerja. Matrik: Jurnal Manajemen, Strategi Bisnis dan Kewirausahaan, 14 (2), 290303. https://doi.org/10.24843/MATRIK:JMBK.2020.v14.i02.p12.

Norhabiba, F., \& Putri, S. A. R. (2018). Hubungan Intensitas Akses Media Baru dan Kualitas Interaksi Lingkungan Sekitar Pada Mahasiswa Untag Surabaya. INTERAKSI: Jurnal Ilmu Komunikasi, 7 (1), 815. https://doi.org/10.14710/interaksi.7.1.8-15.

O'Connor, H., \& Madge, C. (2017). The SAGE Handbook of Online Research Methods. The SAGE Handbook of Online Research Methods.

Pitoy, T. I., Pio, R. J., \& Rumawas, W. (2020). Faktor-faktor Yang Mempengaruhi Loyalitas Karyawan (Studi Pada PT Midi Utama Indonesia Tbk. Branch Manado). Productivity, 1 (4). Retrieved from https://ejournal.unsrat.ac.id/index.php/productivity/article/view/30072.

Prabu, A. S., \& Wijayanti, D. T. (2016). Pengaruh Penghargaan dan Motivasi Terhadap Kinerja Karyawan (Studi Pada Divisi Penjualan PT. United Motors Center Suzuki Ahmad Yani, Surabaya). Jurnal Ekonomi Bisnis dan Kewirausahaan, 5 (2), 104-117. https://dx.doi.org/10.26418/jebik.v5i2.17144.

Putra, T. R. (2017). Analisis Upah Sistem Bagi Hasil Anak Buah Kapal pada Perahu Penangkap Ikan di Kabupaten Lamongan (Studi Kasus Perahu Jenis Ijon-Ijon Payangan pada Masyarakat Nelayan di Kelurahan Brondong dan Kelurahan Blimbing). Media Trend, 12 (2), 168-176. https://doi.org/10.21107/mediatrend.v12i2.3105.

Putriani, Y. (2017). Peran Employee Relations Dalam Upaya Pencapaian Visi dan Misi Best Western Premier Solo Baru. Jurnal Humaniora Yayasan Bina Darma, 4 (2), 165-180. Retrieved from https://jurnalilmiah-paxhumana.org/index.php/PH/article/view/109.

Rachman, L., \& Dewanto, A. (2016). Pengaruh Employee Engagement terhadap Kepuasan Kerja dan Turnover Intention Perawat (Studi pada Rumah Sakit Wava Husada Kepanjen Malang). JAM: Jurnal Aplikasi Manajemen, 14 (2), 322-333. http://dx.doi.org/10.18202/jam23026332.14.2.14.

Rahayu, E. I. H., Suhardoyo, \& Iwan. (2019). Umpan Balik Sistem Pakar Sebagai Penilaian Kinerja Karyawan Pada PT. Multistrada Arah Sarana, Tbk. Business Management Analysis Journal (BMAJ), 2 (1), 52-67. https://doi.org/10.24176/bmaj.v2i1.3211.

Rahmi, F. N., Hafiar, H., \& Subekti, P. (2018). Strategi Employee Relations Management Di PT. Kemfarm Indonesia. Commed: Jurnal Komunikasi dan Media, 2 (1), 36-54. https://doi.org/10.33884/commed.v2i2.469.

Raturoma, J. M. A., \& Wijaya, L. S. (2018). Aktivitas Public Relations dalam Upaya Meningkatkan Citra Taman Wisata Candi Borobudur. Jurnal Ilmu Komunikasi Ultimacomm, 10 (2), 114125.https://doi.org/10.31937/ultimacomm.v10i2.916,

Ready, A. (2016). Penggunaan Media Online Sebagai Sumber Informasi Akademik Mahasiswa Ilmu Komunikasi Fakultas Ilmu Sosial dan Ilmu Politik Universitas Riau. Jom Fisip, 3 (1). Retrieved from https://jom.unri.ac.id/index.php/JOMFSIP/article/view/8438.

Rohandi, M. M. A. (2016). Effective Marketing Communication: Word Of Mouth. Performa: Jurnal Manajemen dan Bisnis, 13 (1), 1-14. https://doi.org/10.29313/performa.v0i1.3502

Ruslan, R. (2018). Manajemen Publik Relation dan Media Komunikasi - Edisi Revisi. Jakarta: PT. Raja Grafindo 
Persada.

Siswanto, S. (2019). Manajemen Tenaga Kerja Indonesia. Jakarta: PT Bumi Aksara.

Suparmi, \& Septiawan, V. (2019). Reward dan Punishment Sebagai Pemicu Kinerja Karyawan Pada PT. Dunia Setia Sandang Asli IV Ungaran. Jurnal Ilmiah UNTAG Semarang, 8 (1), 51-61. Retrieved from http://jurnal.untagsmg.ac.id/index.php/sa/article/view/1134.

Teguh, S., Sari, Y. D., \& Vidyarini, T. N. (2018). Evaluasi Program Employee Relations di Hotel Majapahit Surabaya Managed by Accorhotels Tahun 2017. Jurnal E-Komunikasi Program Studi Ilmu Komunikasi Universitas Kristen Petra, Surabaya, 6 (2), 1-11. Retrieved from http://publication.petra.ac.id/index.php/ilmu-komunikasi/article/view/8329.

Tirto.id. (2020). Lebih Banyak Pekerja Mengundurkan Diri daripada di-PHK Tahun 2019. Retrieved from https://tirto.id/lebih-banyak-pekerja-mengundurkan-diri-daripada-di-phk-tahun-2019-eBdr.

Wasis, N. (2018). Pengaruh Insentif Terhadap Kinerja Karyawan Yang Dimediasi Motivasi Kerja Karyawan Pada PT Sedulur Guyub Rukun Pandanwangi Jombang. Jurnal Riset Manajemen dan Bisnis $\begin{array}{llll}\text { Dewantara, } & 1 & \text { (1). } & \text { Retrieved }\end{array}$ https: //ejournal.stiedewantara.ac.id/index.php/JMD/article/view/256.

Widijanto, K. A. (2017). Pengaruh Pelatihan Kerja dan Motivasi Kerja Terhadap Kinerja Karyawan Divisi Pemasaran di PT Sumber Hasil Sejati Surabaya. AGORA: Jurnal Manajemen Bisnis., 5 (1). Retrieved from http://publication.petra.ac.id/index.php/manajemen-bisnis/article/view/5312. 